\title{
Middle Eocene Ostracoda from Baja California Sur, Mexico
}

\author{
ANA LUISA CARREÑO \\ Instituto de Geología, \\ Universidad Nacional Autónoma de Mexico, \\ Delegación Coyoacan, \\ 04510 D.F., Mexico.
}

\author{
THOMAS M. CRONIN \\ Paleontology \& Stratigraphy Branch, \\ U.S. Geological Survey, \\ Reston, Virginia,
}

U.S.A.

\begin{abstract}
One genus and six new species of ostracodes are described from the Bateque Formation on the Pacific Coast of Baja California Sur, Mexico. Planktonic foraminifers indicate a mid Eocene age and the whole assemblage is characteristic of a shallow warm-water environment. Paijenborchella mezquitalensis sp. nov. is the second record of the genus Paijenborchella from the Eocene of North America. Except for this species and the new genus Bajacythere, the ostracode association has strong affinities with those described from the lower Tertiary Gulf Coast region. J. Micropalaeontol. 12 (2): 141-153, December 1993.
\end{abstract}

\section{INTRODUCTION}

During the last few decades, geological research in the Baja California Peninsula has been focused on the study of deep sea Miocene and Pliocene sequences that were deposited during or immediately after the formation of the Gulf of California. The objective of those efforts has been to understand the origin and evolution of the gulf in relation to neotectonics.

A great part of the Peninsula of Baja California, p.xrticularly its western slope, is covered by lower Cenozoic outcrops that have been assigned to different formational units: the Tepetate Formation (Upper Cretaceous to mid Eocene), the Malarrimo Formation (Paleocene), the Ballenas Formation (Paleocene), the Santo Domingo Formation (Paleocene and only recognised in boreholes), the Sepultura Formation (lower Eocene), and the Bateque Formation (lower and mid Eocene).The sediments referred to as the Bateque (Mina-Uhink,1957) and/or the Tepetate (Heim, 1922) Formations include marine fossiliferous beds containing abundant microfossils.

The main objective of this paper is to document the Ostracoda from the Bateque Formation. The paleozoogeographic and biostratigraphic significance of this fauna is included

\section{MATERIAL AND METHODS}

Two localities of the Bateque Formation yielded the ostracodes discussed in this paper. The first locality (IGM2,515) is located $32 \mathrm{~km}$ southwest of San Ignacio, Baja California Sur, Mexico (Fig. 1), and is the type locality of the Bateque Formation (Mina-Uhink, 1957). Sampling was made in a section at the northern side of Arroyo San Ramón, near Rancho Batequi del Monreal (Rancho

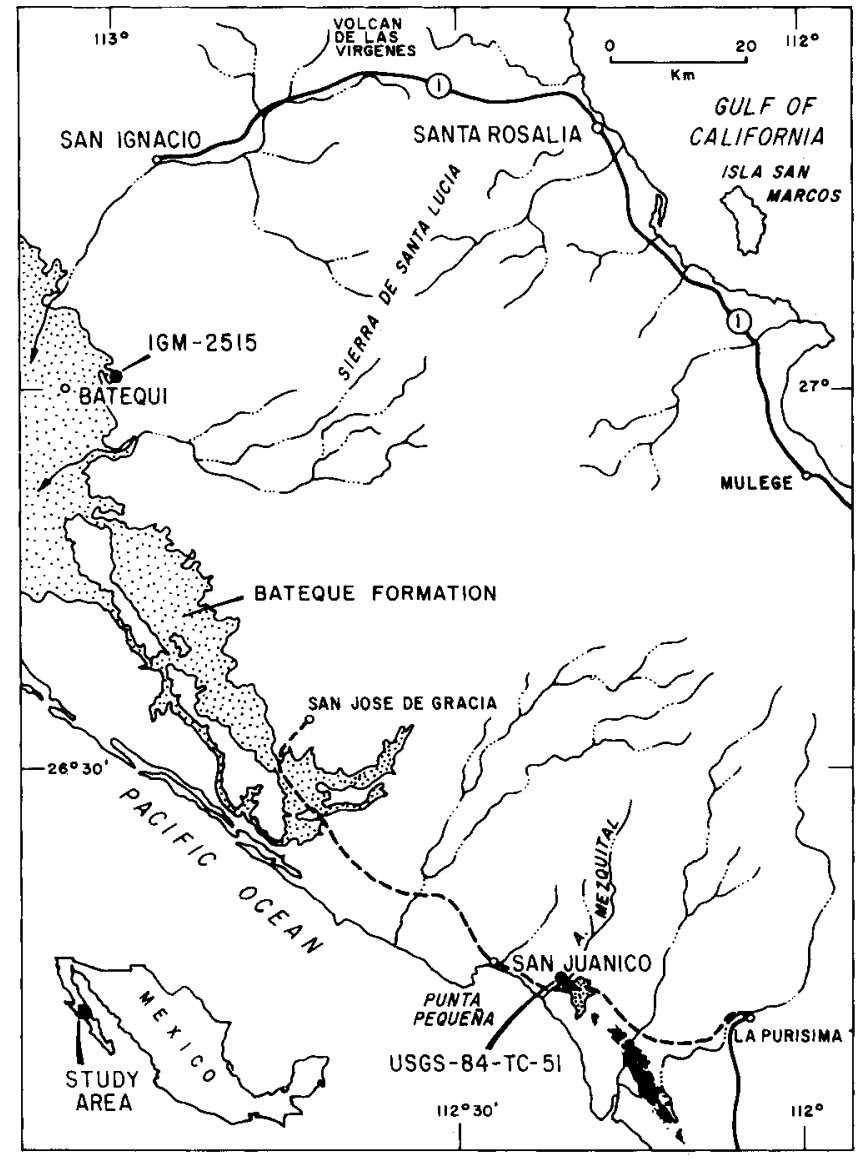

Fig. 1. Location map showing the sampled localities of the Bateque Formation: IGM-2, 515 and the USGS-84TC-51. 
Bateque), approximately $2.5 \mathrm{~km}$ northeast of latitude $27^{\circ} 00^{\prime} \mathrm{N}$ and longitude $113^{\circ} 00^{\prime} \mathrm{W}$ (San José de Gracia Quadrangle, Baja California Sur, Mexico, 1: 50,000 chart number G12A64, INEGI, 1983). The measured section is 52 $m$ thick and consists mainly of medium to very fine micaceous, feldspathic sandstone with interbedded fossiliferous lenses and siltstones. The base of the formation is not exposed; the unit is unconformably overlain by the Miocene volcanics of the San Isidro Formation. The ostracode collection comes from 16 to $40 \mathrm{~m}$ above the base of the outcrop, where fossiliferous lenses bearing discocyclinids occur.

The second locality (USGS-84TC51) is a north-facing $35 \mathrm{~m}$ high bluff at the southern side of Arroyo Mezquital (Fig. 1), just south of the dirt road leading to San Juanico $(13.5 \mathrm{~km}$ to north $26^{\circ} 14^{\prime} \mathrm{N}-112^{\circ} 23^{\prime} \mathrm{W}$, San Isidro Quadrangle, Baja California Sur Mexico, 1: 250, 000 chart number NG12-4, CGSNEGI, 1982). The ostracode samples were collected at the base of a $30 \mathrm{~m}$ thick section, that consists of very weathered reddish-gray mudstone and very fine-grained sandstone beds. From the two localities, 30 samples were examined for ostracodes. Detailed geological map and information including both localities was published by McLean and coworkers $(1985,1987)$.

\section{BIOSTRATIGRAPHIC FRAMEWORK}

Mina-Uhink (1957) studied several localities from this area and considered that the Bateque Formation was deposited during the early and mid Eocene, based on the presence of Turritella pachecoensis Stanton, Morozovella aragonensis (Nuttall) and Acarinina crassata (Cushman). Carrillo de Isolbi (1976) assigned a later early Eocene and mid Eocene age to the outcrops exposed in the PEMEX San IgnacioCadejé Project, based on the planktonic foraminifers and calcareous nannoplankton.

From the Arroyo San Raymundo section, located near our Arroyo Mezquital locality, McLean \& Barron (1988) recovered a diatom assemblage assigned to the Triceratium inconspicuum var. triloba Partial Range Zone, equivalent to a later mid Eocene age.

Recently, Squires \& Demetrion (1989, 1990a, 1990b), based on the presence of Morozovella aragonensis (Nuttall) and $M$. caucasica (Glaessner), gave a later early Eocene age to a locality closely situated to the ICM-2,515-UNAM locality and, based on the calcareous nannofossils content, a mid Eocene age (Discoaster bifax - CP14a Zone of Okada \& Bukry, 1980) to locality USGS-84TC51.

The ostracodes recovered at locality IGM-2,515-UNAM are associated with very abundant Pseudophragmina (Proporocyclina) flintensis (Cushman) and Amphistegina lopeztrigoi (Palmer), suggesting a mid Eocene age (Butterlin, 1981).

The presence at locality USGS-84TC51 of Morozovella aragonensis and Truncorotaloides topilensis (Cushman), associated with Turborotalia cerroazulensis pomeroli (Toumarkine \& Bolli), "Globigerinoides" higginsi Bolli and Globigerinatheka subconglobata subconglobata (Shutskaya), indicates an age earlier than mid Eocene, equivalent to the upper Hantkenina nuttalli - Globigerinateka subconglobata subconglobata zones of Toumarkine \& Luterbacher (1985).

\section{SYSTEMATIC PALAEONTOLOGY}

Only new taxa are systematically treated here. The reduced number of specimens, poor preservation and/or the presence of closed carapaces, did not allow the assignment of Hazelina, Pokornyella, Buntonia, "Triginglymus", Loxoconcha, Paracytheridea and Paracypris to new species; thus, these new forms are illustrated and left in open nomenclature. Smooth and/or very fragile carapaces or valves are not illustrated. All measurements were done with an eyepiece micrometer and are given in millimeters. Each valve or carapace was considered as an individual. Primary and secondary types have been deposited in the Instituto de Geología, micropaleontological collection at the Universidad Nacional Autónoma de Mexico (IGM- -Mi). Abbreviations used in this section and in plate captions are: $R V=$ right valve; $L V=$ left valve; $C=$ carapace; $L=$ length; $H=$ height.

$$
\begin{aligned}
& \text { Subclass Ostracoda Latreille, } 1806 \\
& \text { Order Podocopida Müller, } 1894 \\
& \text { Suborder Platycopa Sars, } 1866 \\
& \text { Family Cytherellidae Sars, } 1866 \\
& \text { Genus Cytherella Jones, } 1849 \\
& \text { Cytherella spp. }
\end{aligned}
$$

Remarks. Cytherella occurs rather commonly in the Bateque Formation. Two groups can be recognised based on shape: one with an ovate outline, and the other subquadrate. We do not fully understand the Cytherella in our material; thus, it does not seem advisable to give specific designations to the material studied herein.

Hypotypes. RV ovate form IGM-302-Mi; LV ovate form IGM-303-Mi; carapace ovate form IGM-304-Mi; RV subquadrate form IGM-305-Mi; LV subquadrate form IGM306-Mi; carapace subquadrate form IGM-307-Mi.

Material. Ovate form, 33 specimens; subquadrate form, 22 specimens.

Distribution. Present at locality IGM 2,515

Suborder Podocopa Sars, 1866

Family Bairdiidae Sars, 1866

Genus Bairdoppilata Coryell, Sample \& Jennings, 1935 Bairdoppilata spp.

Remarks. The material is poorly preserved, and mostly consists of carapaces. Two groups, based on shape can be recognised; one group is of large, subpyriform and inflated forms, similar to Bairdoppilata taxodonta Howe \& Law (1935). Forms in the other group are also large sized, but elongated, sharply pointed posteriorly and broadly pointed anteriorly. They resemble Bairdoppilata vernoni Howe (1951).

Hypotypes. RV inflated form IGM-308-Mi; LV inflated form IGM-309-Mi; carapace inflated form IGM-310-Mi; RV elongate form IGM-311-Mi; LV elongate form IGM-312-Mi; carapace elongate form IGM-313-Mi.

Material. 115 specimens of the elongate form and 87 specimens of the inflated form.

Distribution. Locality IGM 2,515 
Family Cytheridae Baird, 1850

Subfamily Cytherinae Baird, 1850

Tribe Paijenborchellini Deroo, 1960

Genus Paijenborchella Kingma, 1948

Paijenborchella mezquitalensis Carreño \& Cronin, sp. nov

$$
\text { (Pl } 1 \text { figs 1-3) }
$$

Derivation of name. After Arroyo Mezquital, Baja California Sur, Mexico.

Diagnosis. Carapace small, thick, ventrally inflated with a deep median sulcus and longitudinal ridges; wide anterior fringe bearing at the RV six larger pits parallel to the anterior margin; at the $L V$ an anterior flange with an irregularly dentate fringe; dorsal margin obscured by four strong like-spine projections.

Holotype. LV female IGM-314-Mi.

Material. 140 specimens

Locality and horizon. Locality USGS-84TC51 on the southern side of Arroyo Mezquital, near San Juanico $\left(26^{\circ} 14^{\prime} \mathrm{N}-112^{\circ} 23^{\prime} \mathrm{W}\right)$, Baja California Sur, Mexico. Bateque Formation, mid Eocene age. Unconsolidated foraminiferarich, fine-grained sandstone.

Description. Carapace small, thick, highest at the anterior cardinal angle; widest posterior to the center. Dorsal margin of the LV is almost straight and slightly inclined, dipping posteriorly with four strong spine-like projections, the dorsal margin of the RV straight; ventral margin strongly convex; anterior margin broadly rounded, bearing at the RV six large parallel pits and at the $L V$, the anterior flange being an irregular dentate fringe. Posterior margin subtriangular, with caudal process. Surface ornamentated by a deep median sulcus, longitudinal ridges, pits, and irregular reticulate pattern; sulcus extends ventrally from anterior cardinal angle, terminating against a prominent ventral longitudinal ridge; between this ridge and ventral margin, a short, weak ridge; a shorter prominent ridge bridges the sulcus near center line; surface anteriorly smooth, most part of the valve coarsely and evenly pitted; mid-posterior surface rough, following an irregular reticulated pattern. Cardinal tubercle prominent.

Inner lamella wide, line of concrescence and inner margin coincide throughout; hinge of the LV with an anterior large socket and postjacent crenulate tooth connected by narrow crenulate median element to subrounded posterior socket. Radial pore canals straight and numerous; muscle scars obscured. Sexual dimorphism strong, males larger than females.

Dimensions. (mm)

Holotype LV

Paratype RV

female

female

female

Paratype LV

male

male

Allotype C

female

$\begin{array}{ll} & \mathrm{L} \\ \text { IGM-314-Mi } & 0.411 \\ \text { IGM-315-Mi } & 0.405 \\ \text { IGM-316-Mi } & 0.415 \\ \text { IGM-317-Mi } & 0.320 \\ \text { IGM-318-Mi } & 0.340 \\ \text { IGM-319-Mi } & 0.405\end{array}$

$\mathrm{H}$

0.240

0.236

0.242

0.160

0.220

0.221

Remarks. Paijenborchella mezquitalensis sp. nov. has four spine-like strong projections in LV instead of a dorsal ridge as present in Paijenborchella trigona Marianos \& Valentine (1958); also, the median ridge is only developed posteriorly to the sulcus; an additional short, weak ridge is ventrally present and the caudal process is strongly upturned.
Distribution. Locality USCS-84TC51

Paijenborchella trigona Marianos \& Valentine, 1958 (Pl 1 figs 4-6)

1958 Paijenborchella trigona Marianos \& Valentine: p. 367, pl. 2 , figs. 3a-b, 4, 5a-b

Diagnosis. Carapace small, ornamentated with a deep median sulcus, longitudinal ridges, pits and a short caudal process.

Hypotypes. LV female IGM-320-Mi; RV male IGM-321-Mi; $\mathrm{C}$ male IGM-322-Mi; RV male IGM-323-Mi; C male IGM324-Mi.

Material. 103 specimens.

Remarks. See P. mezquitalensis Carreño \& Cronin, sp. nov. Distribution. This species was described from the Eocene Capay Formation at Marysville Buttes, Sacramento Valley, California. In Baja California Sur, it was found only at locality IGM-2,515

Family Trachyleberididae Sylvester-Bradley, 1948

Subfamily Trachyleberidinae Sylvester-Bradley, 1948

Tribe Trachyleberidini Sylvester-Bradley, 1948

Genus Acanthocythereis Howe, 1963

Acanthocythereis washburni (Stephenson, 1944)

(Pl 1 figs 7-8)

1944 Cythereis washburni Stephenson: p. 452, pl. 76, fig. 8.

Diagnosis. Carapace medium sized, thick, robust, subrectangular in lateral view. Dorsal and ventral margins nearly straight and gently converging towards subangular posterior end; anterior margin broadly rounded. Anterior and posterior margins bear denticulations that are most prominent ventrally. Dorsal margin slightly obscured by a row of large, rounded, nearly pointed nodes. Surface coarsely reticulated, deep and polygonal pits surrounded by ridges of nearly equal height bearing blunt rounded nodes at their intersections. Anterior with five to six large blunt rounded nodes. Eye tubercle very prominent, nearly surrounded by blunt nodes. Hinge of RV with a blunt, anterior tooth connected by a narrow, smooth, straight dorsal furrow to a large subpyramidal posterior tooth, LV complementary. Radial pore canals, numerous and straight. Muscle scars obscured.

Hypotypes. LV IGM-325-Mi; C IGM-326-Mi; RV IGM-327Mi.

Material. 33 specimens.

Remarks. In spite of the fact that the Bateque Formation specimens have lost most of their surface spines, due to preservation effect, they appear to be identical to $A$. washburni (Stephenson, 1944), described from the mid Eocene Reklaw Formation, Bastrop Country, Texas.

Distribution. Locality IGM 2, 515, and Bastrop County, Texas.

Genus Bajacythere Carreño \& Cronin, gen. nov. Type species. Bajacythere bajaensis Carreño \& Cronin, sp. nov. Derivation of name. After Baja California Sur, Mexico. Diagnosis. A trachyleberidinid genus characterized by medium size; thinly calcified; subrectangular, laterally compressed carapace; asymmetrical valves, the LV higher 
anterodorsally with a thick subrounded projection extending over the RV; denticulate anterior and posterior margins; smooth and polished with few and widely distributed, apparently open normal pore canals; two submedian parallel ridges; narrow ventral ridge extending from anteroventral margin to posteroventral end; moderate broad anterior rim; eye tubercle present; moderately broad inner lamella, narrowing ventrally; moderate number of long, wavy marginal pore canals; holamphidont hinge; four elongated adductor scars in a vertical row; V-shaped frontal scar.

Remarks. This genus is distinguished from other trachyleberidinid tricostate genera by its broad inner margin. It resembles Occultocythereis but differs by its larger size, the presence of a prominent submedian ridge and simple, long and sinuous marginal pore canals. Phacorhabdotus is similar, but its carapace is much shorter, its anterior frill is thin, it has no marginal ridge, its muscle swelling is pronounced, and its pore canals are paired.

In its general outline and the characteristic strong hinge, Bajacythere resembles Recent Australian Cythereis (Cythereis) cristatella Brady (1866), later reported by Brady (1880) as Cythere cristatella from Recent sediments off Booby Island, southern New Guinea.

\section{Bajacythere bajaensis Carreño \& Cronin, sp. nov.}

(Pl 1 figs 9-13)

Derivation of name. After Baja California Sur, Mexico.

Diagnosis. A tricostate species characterized by a smooth and polished surface with small deep pits, moderately broad inner margin; denticulate anterior and posterior margins, valves asymmetrical.

Holotype. LV female IGM-328-Mi

Material. 40 specimens.

Locality and horizon. Locality USGS-84TC51 southern side of Arroyo Mezquital, near San Juanico (26 $6^{\circ} 14^{\prime} \mathrm{N}-112^{\circ} 23^{\prime} \mathrm{W}$ ), Baja California Sur, Mexico. Bateque Formation, mid Eocene age. Unconsolidated foraminifera-rich, fine-grained sandstone.

Description. Carapace with greatest height at the anterior cardinal angle; greatest width at the posterior end of the submedian ridge; $L V$ with a thick subrounded hinge earlike projection anterior to the eye node. Narrowly cuneiform in dorsal view, compressed in the anterior and posterior with truncated extremities. Dorsal and ventral margins almost straight in lateral view; anterior margin broadly rounded with 20-25 denticles; posteroventrally denticulate, postdorsal and postventral margins forming a blunt angle. Surface smooth and polished; two longitudinal and parallel ridges extending about half the length of the carapace, rising from anteromedial area and terminating posteromedially; marginal rim low; ventral ridge oblique, extending from the mid-anteroventral margin to the posterior end of the median ridges; normal pore canals open and moderate in number. Inner lamella moderately broad, narrowing ventromedially; line of concrescence and inner margin coincide throughout; marginal pore canals simple, long, wavy with distal thickening; selvage prominent, peripheral. Hinge in the RV with a strong tooth having a higher large and rounded distal part, a lower reniform proximal part and a large postjacent socket anteroventrally opened to the inside; median groove straight and smooth; posterior tooth large rounded. LV complementary. Sexes distinct, males longer and lower than females.

$\begin{array}{lccll}\text { Dimensions (mm) } & & \text { L } & \mathrm{H} \\ \text { Holotype LV } & \text { female } & \text { IGM-328-Mi } & 0.730 & 0.411 \\ \text { Paratype RV } & \text { female } & \text { IGM-329-Mi } & 0.670 & 0.340 \\ \text { Paratype RV } & \text { female } & \text { IGM-330-Mi } & 0.690 & 0.370 \\ \text { Allotype LV } & \text { male } & \text { IGM-331-Mi } & 0.770 & 0.380 \\ \text { Allotype C } & \text { male } & \text { IGM-332-Mi } & 0.670 & 0.370 \\ \text { Allotype RV } & \text { male } & \text { IGM-333-Mi } & 0.745 & 0.380\end{array}$

Remarks. This species was compared with material deposited at the Reston, Virginia, United States Geological Survey collection assigned by Cronin (unpublished report) to the upper Miocene "Capricornia" cristatella (Brady, 1866), from Enewetak Atoll, Marshall Islands, Equatorial Pacific Ocean boreholes. This Micronesian species is very similar to Bajacythere bajaensis Carreño \& Cronin, sp. nov., particularly with respect to the strong hinge both have, but it differs in having a smooth surface and a moderately broad inner

\section{Explanation of Plate 1}

Figs. 1-3. Paijenborchella mezquitalensis sp. nov. Carreño \& Cronin. Locality USGS-84TC51. All specimens are approximately X 130: fig. 1, Holotype IGM-314-Mi, female LV, external view; fig. 2, Paratype IGM-315-Mi, female RV, external view; fig. 3, Paratype IGM-316$\mathrm{Mi}$, female $\mathrm{LV}$, internal view.

Figs. 4-6. Paijenborchella trigona Marianos \& Valentine, 1958. Locality IGM-2, 515. All specimens are approximately X 130; fig. 4, Hypotype IGM-320-Mi, female LV, external view; fig. 5, Hypotype IGM-321-Mi, male RV, external view; fig. 6, Hypotype IGM-322Mi, male $C$, dorsal view.

Figs. 7-8, Acanthocythereis washburni (Stephenson 1944). Locality IGM-2, 515, All specimens are approximately X 60; fig. 7, Hypotype IGM-325-Mi, LV, external view; fig. 8, Hypotype IGM-326-Mi, C, dorsal view.

Figs. 9-13, Bajacythere bajaensis gen. nov., sp. nov., Carreño \& Cronin. Locality USGS-84TC51. All specimens are approximately X 60: fig. 9, Holotype IGM-328-Mi, female LV, external view; fig. 10, Paratype IGM-329-Mi, female RV, external view; fig. 11, Paratype IGM-330-Mi, female RV, internal view; fig. 12, Allotype IGM-331-Mi, male LV, external view; fig. 13, Paratype IGM-332-Mi, female C, dorsal view.

Figs.14-16 Hazelina sp. Locality IGM-2, 515. All specimens are approximately X 100: fig. 14, Hypotype IGM-334-Mi, C, dorsal view; fig. 15, Hypotype IGM-335-Mi, C, external view of the RV; fig. 16, Hypotype IGM-336-Mi, C, external view of the LV.

Figure 17-19, Occultocythereis gioargaezi Carreño \& Cronin, sp. nov. Locality USGS-84TC51. All specimens are approximately X100; fig. 17, Holotype IGM-337-Mi, C, dorsal view; fig. 18, Paratype IGM-338-Mi, RV, external view; fig. 19, Paratype IGM-339-Mi, LV, external view. 


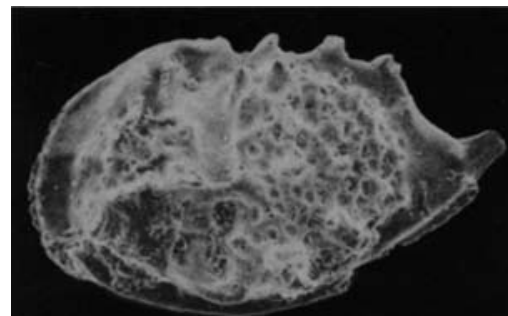

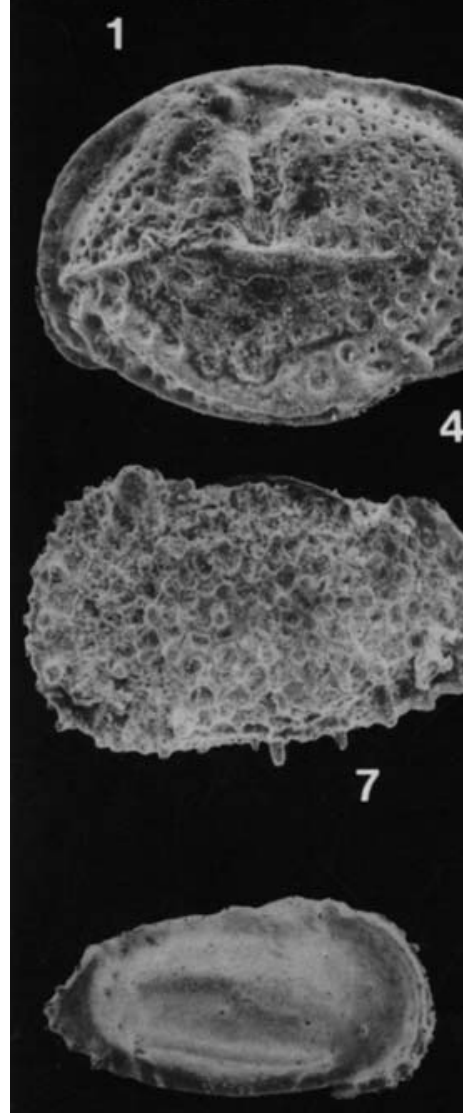

10

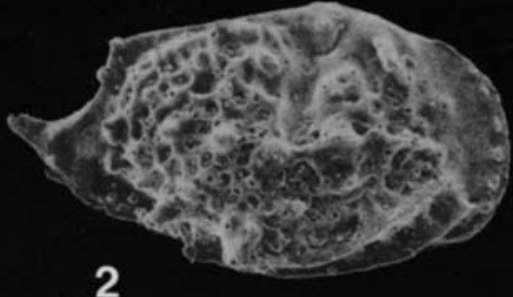

2
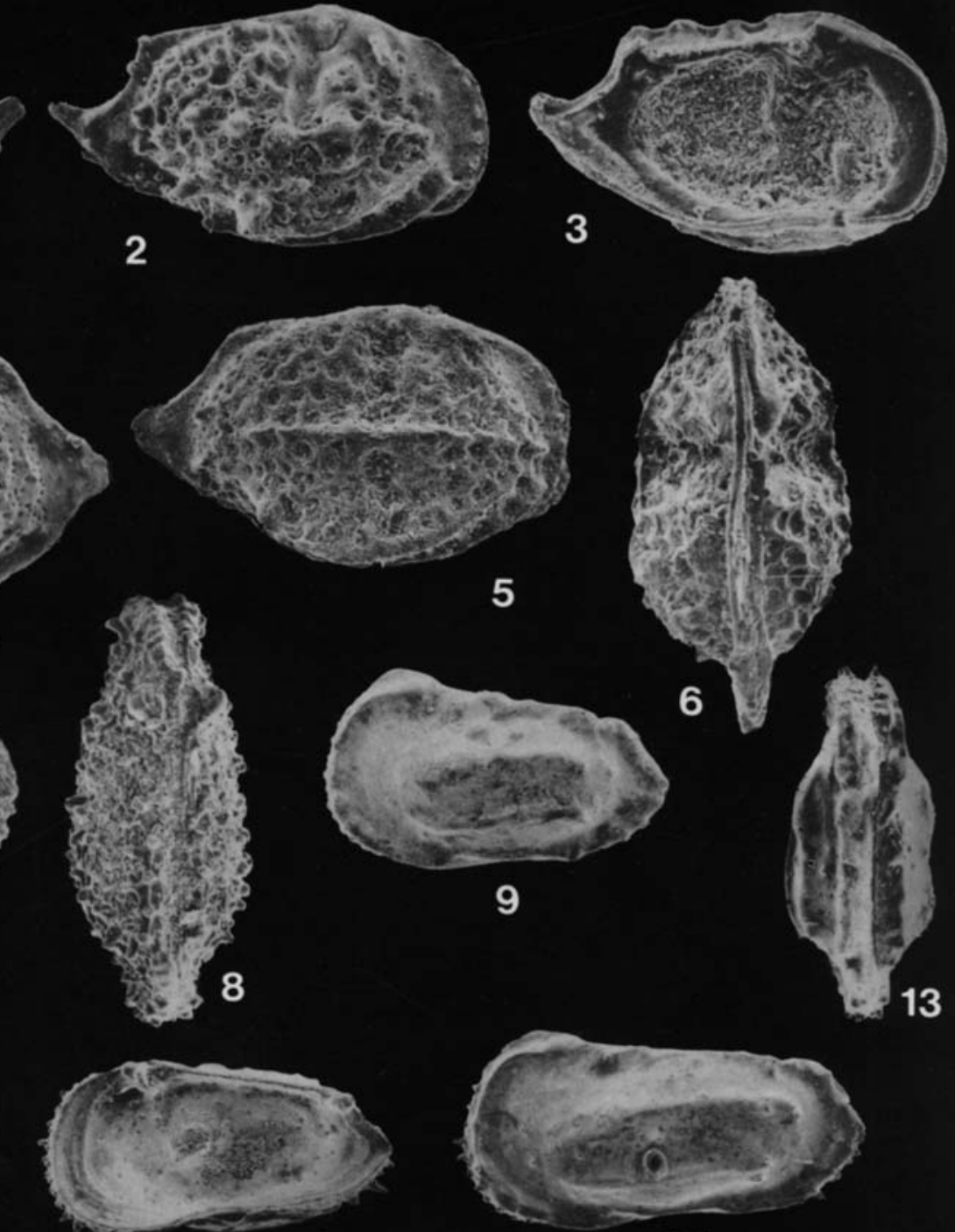

11
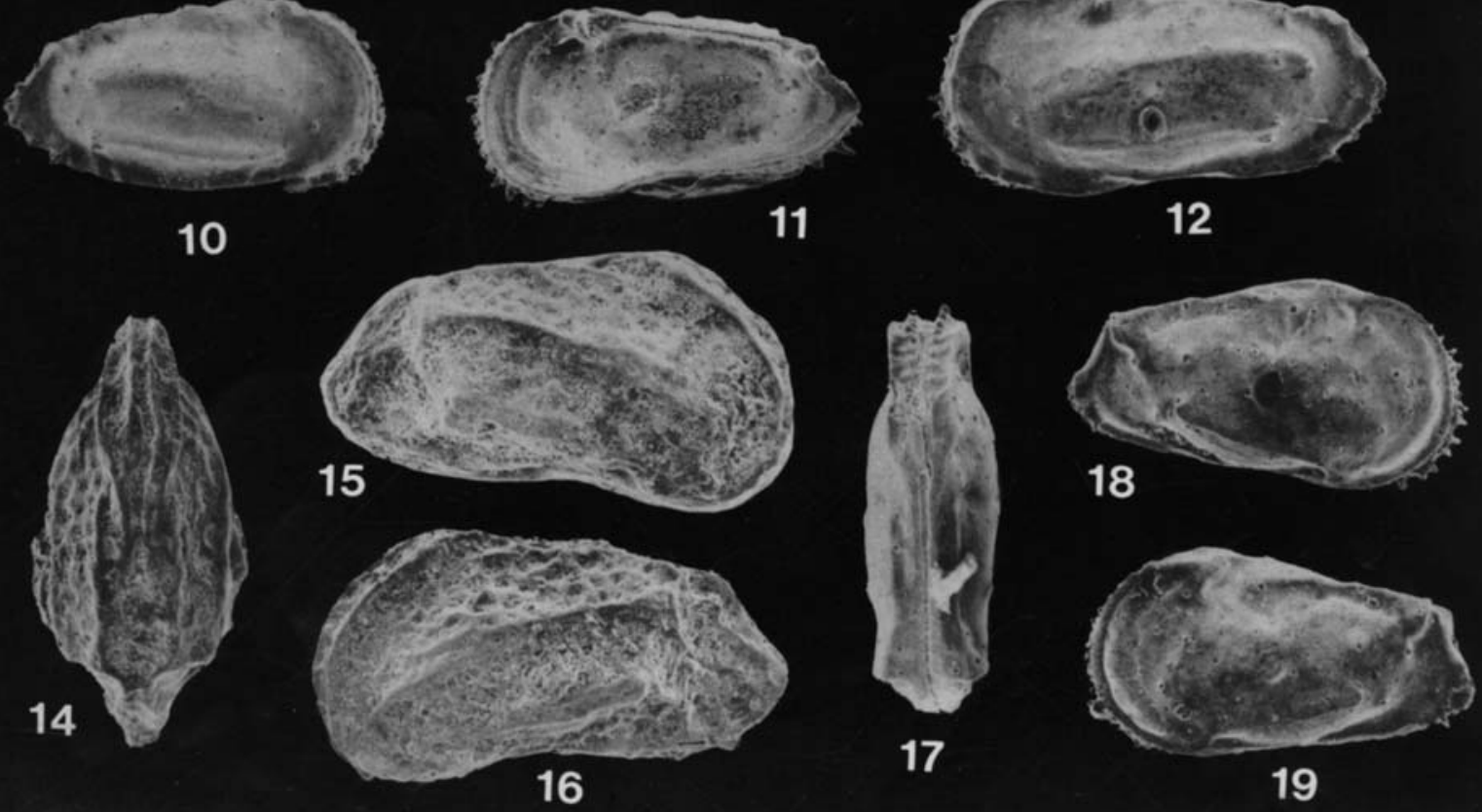
margin instead of a finely pitted surface and broad inner margin.

Distribution. Locality USGS-84TC51.

\section{Genus Hazelina Moos,1966 Hazelina sp. \\ (Pl 1 figs 14-16)}

Description. Small sized carapace, subrectangular in lateral view, highest at the anterior cardinal angle, widest at $1 / 3$ of the posterior margin. Dorsal margin nearly straight, ventral slightly convex at center, both converging toward the posterior. Anterior end, broadly and obliquely rounded and fringed, with a parallel to it rim carrying small anteroventral denticles. Posterior end compressed, dorsally subangular, slightly convex ventrally. Valves surface covered with a polygonal reticulated pattern. Three low ridges almost parallel extend obliquely backward from about $1 / 3$ behind the anterior margin to a point near the posterior cardinal angle, where they join by means of a short, and weak ridge forming a strong angular projection. Eye tubercle small and indistinct. Internal characters not observed.

Hypotypes. C IGM-334-Mi; C IGM-335-Mi and C IGM-336-Mi. Material. 11 specimens.

Remarks. This species is similar to Hazelna couleycreckensis (Gooch, 1939), but differs in that the submedian ridge in Hazclina sp. goes obliquely from near the anteroventral margin; the posteroventral margin lacks prominent spines and is also smaller. Due to the small number of specimens, all of which are carapaces, it was preferred to leave this species in open nomenclature.

Distribution. Locality IGM 2, 515.

Genus Occultocythereis Howe, 1951

Occultocythereis gioargaezi Carreño \& Cronin sp. nov. (Pl 1 figs 17-19)

Derivation of name. After Professor Raúl Gío-Argáez, U.N.A.M.

Diagnosis. Carapace small, thinly calcified; subrectangular, laterally compressed. Surface smooth with ventral and dorsal short ridges. Dorsal and ventral margins nearly straight; rounded anterior margin denticulated throughout being a thick, low rim; posterior margin narrower, angular below the middle, bcaring denticles posteroventrally.

Holotype. C IGM-337-Mi

Material. 37 specimens.

Locality and horizon. Locality USGS-84TC51, southern side of Arroyo Mezquital, near San Juanico (26 $\left.14^{\prime} \mathrm{N}-112^{\circ} 23^{\prime} \mathrm{W}\right)$,
Baja California Sur, Mexico. Bateque Formation, mid Eocene age. Unconsolidated foraminifera-rich, fine-grained sandstone.

Description. Carapace small, thinly calcified; subrectangular, laterally very compressed; highest at the anterior cardinal angle, widest at the posterior end of the dorsal ridge; valves slightly asymmetrical, LV moderately overlapping RV anterodorsally. Dorsal and ventral margins nearly straight converging toward posterior end. Anterior margin rounded and denticulated throughout with a thick, low rim; posterior margin narrower, angular below the middle bearing five denticles. Surface smooth, normal pore canals widely spaced; a short, low ridge extends from a depression located behind the eye tubercle and runs subparallel to the dorsal margin reaching the posterior cardinal angle where it turns down sharply forming an angular projection. A short ventral ridge extends $1 / 3$ from the anterior end, running obliquely upward to end abruptly $1 / 3$ before reaching the posterior margin forming a blunt projection. Internally, the valves are shallow; inner lamella moderately broad, narrowing ventromedially and incurved; line of concrescence and inner margin coinciding throughout; marginal pore canals straight and moderate in number. Hinge of the RV consists of a large, sharply anterior tooth behind which is a rounded deep socket; median groove straight and finely crenulated; posterior cardinal angle with a large blunt tooth. The LV complementary. Muscle scars consisting of a slightly oblique row of four rounded scars; single V-shaped frontal scar. Sexual dimorphism not observed.

$\begin{array}{lcll}\text { Dimensions (mm) } & \text { L } & \text { H } \\ \text { Holotype C } & \text { IGM-337-Mi } & 0.416 & 0.140 \\ \text { Paratype RV } & \text { IGM-338-Mi } & 0.415 & 0.140 \\ \text { Paratype ILV } & \text { IGM-339-Mi } & 0.405 & 0.140\end{array}$

Remarks. In its general outline, this species resembles Occultocy thereis broussardi (Howe \& Chambers, 1935), but differs in that the species of Baja California is smaller, has a more depressed carapace, and the posterior end of both valves is angular below the middle, and has fine denticles; it has also small, rounded denticles throughout the greater part of the anterior end; dorsal rim is not present.

Distribution. Locality USGS-84TC51.

Subfamily Hemicytherinae Puri, 1953

Tribe Thaerocytherini Hazel, 1967

Genus Hermanites Puri, 1955

Hermanites batequensis Carreño \& Cronin sp. nov.

\section{Explanation of Plate 2}

Figs. 1-4, Hermanites batequensis sp. nov. Carreño \& Cronin. Locality USGS-84TC51. All specimens are approximately X 80: fig. 1, Holotype IGM-340-Mi, LV, external view; fig. 2, Paratype IGM-341-Mi, RV; external view; fig. 3, Paratype IGM-342-Mi, RV, internal view. fig. 4, Paratype IGM-343-Mi, C, dorsal view.

Figs. 5-8, Jugosocythere is bermejoensis sp. nov. Carreño \& Cronin. Locality USGS-84TC51. All specimens are approximately X 80: fig. 5, Holotype IGM-344-Mi, LV, external view; fig. 6, Paratype IGM-345-Mi, RV, external view; fig. 7, Paratype IGM- 346-Mi, C, dorsal view; fig. 8, Paratype IGM-347-Mi, LV, internal view.

Figs. 9-12, Jugosocythkreis montealensis sp. nov. Carreño \& Cronin. Locality IGM-2, 515. All specimens approximately X 80; fig. 9, Holotype IGM-348-Mi, female LV, external view, fig. 10, Paratype IGM-349-Mi, female RV, internal view; fig. 11, Allotype IGM-350Mi, male RV, external view; fig. 12, Paratype IGM-351-Mi, female C, dorsal view. 


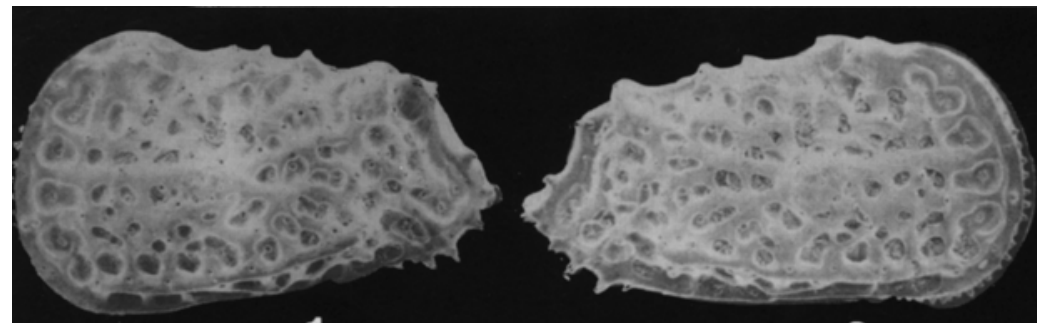

1

2
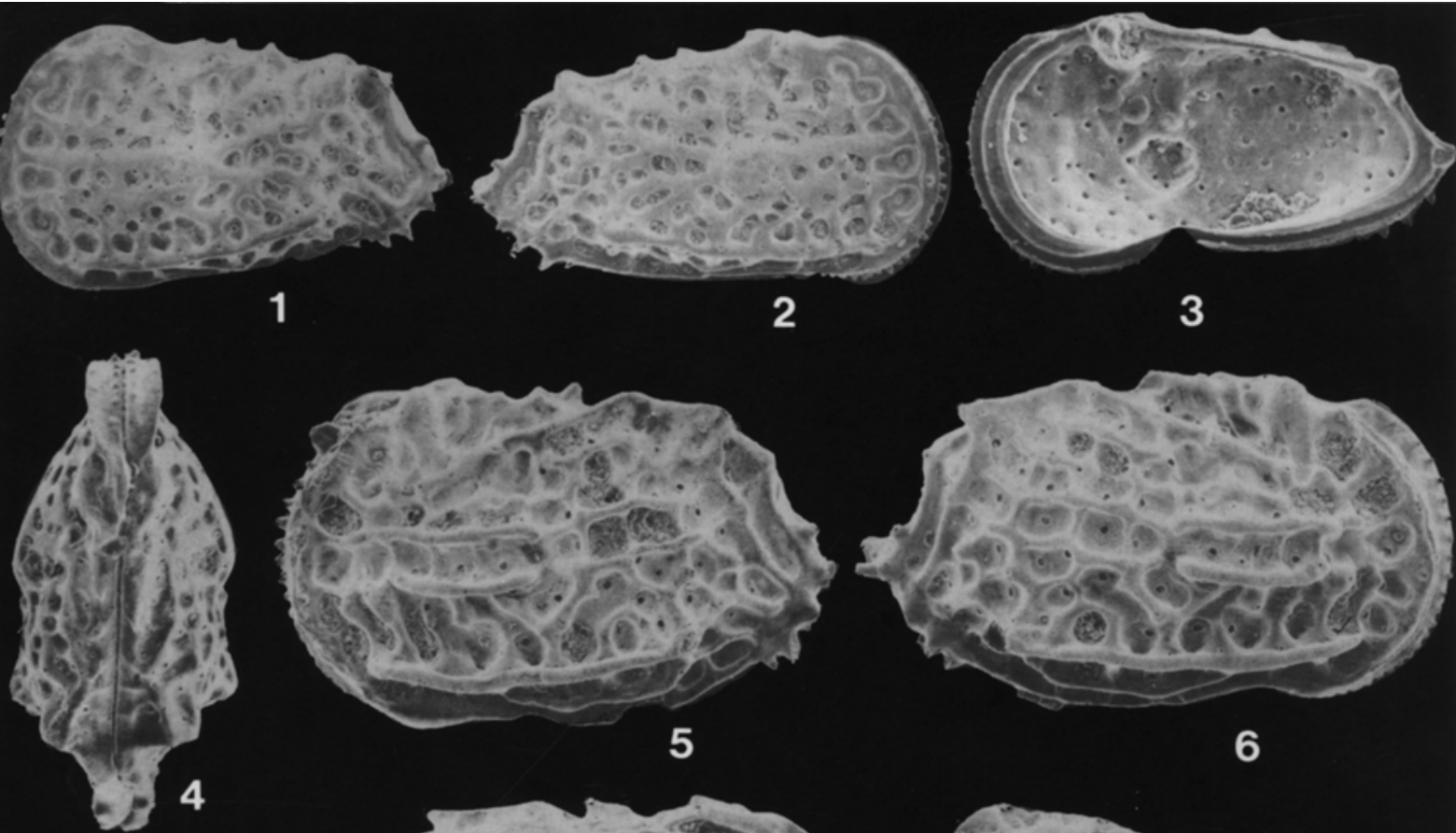

5

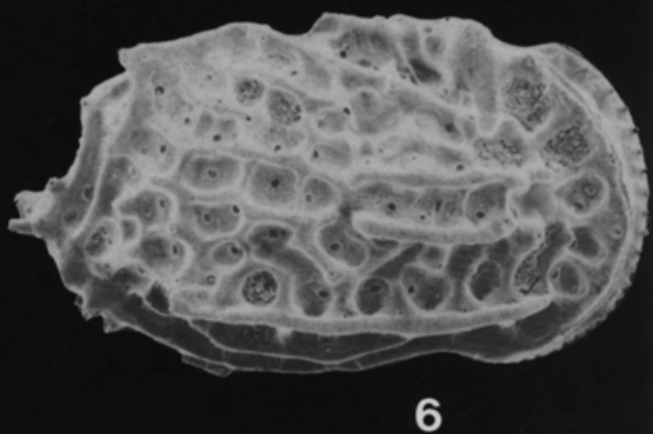

6

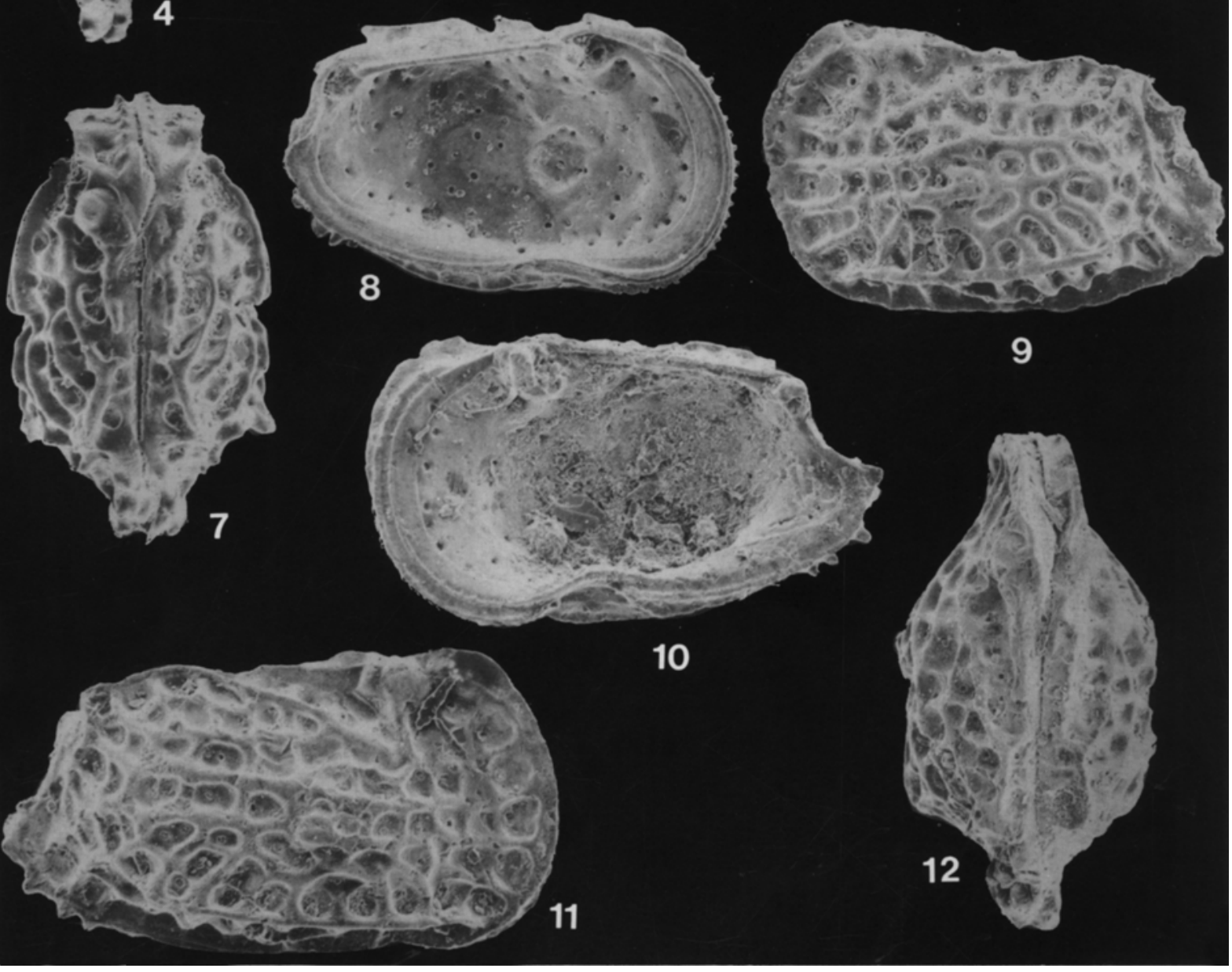


(Pl 2 figs 1-4)

Derivation of name. Derived after the formational name Bateque.

Diagnosis. Characterized by an elongated, subrectangular carapace, with dorsal and ventral ridges and a very low, submedian ridge, surface of the valves foveolate, anterior margin denticulate, and the posterior end bearing marginal spines.

Holotype. LV IGM-340-Mi.

Material. 30 specimens.

Locality and horizon. Locality USGS-84TC51 southern side of Arroyo Mezquital, near San Juanico $\left(26^{\circ} 14^{\prime} \mathrm{N}-112^{\circ} 23^{\prime} \mathrm{W}\right)$, Baja California Sur, Mexico. Bateque Formation, mid Eocene age. Unconsolidated foraminifera-rich, fine-grained sandstone.

Description. Medium sized carapace; with flattened extremities in dorsal view, in lateral view elongated, subrectangular, greatest height at the anterior cardinal angle, greatest width posteriorly due to the projection of the posterior end of the submedian ridge. Dorsal margin almost straight, ventral margin of LV concave, RV almost straight. Anterior margin broadly and obliquely rounded, fringed with numerous small denticles, posterior margin truncated in the LV, at the RV its dorsal portion is concave, in both valves the ventral portion bears five marginal spines and two in the dorsal portion. Subcentral swelling low, surface of valves foveolate with strong coarse pits projecting over the dorsal margin, with a very low dorsal ridge, a rounded knob at the posterior cardinal angle. A low, rounded submedian ridge starting at the anterior margin runs back to the central swelling where it becomes more evident, turning upwards and ending at the rounded knob of the posterior cardinal angle. Another ridge runs parallel to the ventral margin in the $R V$, whereas in the $L V$ it runs obliquely to the ventral margin.

Inner lamella moderately wide, line of concrescence and inner margin coincide, radial pore canals straight and numerous. Central muscle scars consist of a posterior vertical row of four elongated scars, with two closely situated frontal scars. Hinge of RV consists of a high conical anterior tooth, a postjacent socket connected by a straight groove to a lobed posterior tooth, hinge of LV complementary. Marginal pore canals numerous, simple and straight, dorsally widely spaced, anteriorly paired, and ventrally numerous and closely spaced.

Dimensions (mm)

$\begin{array}{llll}\text { Holotype LV } & \text { IGM-340-Mi } & 0.610 & 0.360 \\ \text { Paratype RV } & \text { IGM-341-Mi } & 0.650 & 0.340 \\ \text { Paratype RV } & \text { IGM-342-Mi } & 0.640 & 0.340 \\ \text { Paratype C } & \text { IGM-343-Mi } & 0.650 & 0.340\end{array}$

Remarks. This species was placed in the genus Hermanites because of the general outline, ornamentation and hinge; nevertheless, the dorsal ridge is not well-developed. Also, an unusual low submedian ridge is present, possibly due to the replacement of foveolate with reticulated pattern of ornamentation. Hermanites batequensis sp. nov. resembles $H$. paijenborchiana (Keij, 1957) from the mid Eocene (Lutetian) of Grignon, France. It is different from $H$. batequensis sp. nov. because it lacks the submedian ridge and a welldeveloped reticulated pattern.

Distribution. Locality USGS-84TC51

Genus Jugosocythereis Puri, 1957

Jugosocythereis bermejoensis Carreño \& Cronin, sp. nov. (Pl 2 figs 5-8)

Derivation of name. Referring to the original Spanish name of the Gulf of California: "Mar Bermejo".

Diagnosis. Carapace subquadrate in lateral view; straight dorsal and sinuous margin; anterior margin rounded, with denticles and a heavy rim; posterior end short, subrounded with five strong spines. Surface covered with weak reticulation, ventral and dorsal ridges, and two subparallel longitudinal median ridges.

Holotype. LV IGM-344-Mi.

Material. 67 specimens.

Locality and horizon. Locality (USGS-84TC51) southern side of Arroyo Mezquital, near San Juanico (26 $14^{\prime} \mathrm{N}$ $\left.112^{\circ} 23^{\prime} \mathrm{W}\right)$, Baja California Sur, Mexico. Bateque Formation, mid Eocene age. Unconsolidated foraminiferal-rich, finegrained sandstone.

Description. Carapace subquadrate in lateral view with an almost straight dorsal margin and slightly sinuous ventral margin; greatest height at the anterior cardinal angle; greatest width at the posterior end of the projecting ribs. Anterior margin almost evenly rounded, wider dorsally than ventrally, with about 20 denticles along a heavy marginal ridge. This ridge merges with the anteroventral margin, ending dorsally in a moderate eye tubercle; posterior end short, laterally compressed, angled subventrally, concave above, subrounded and with five strong spines. In dorsal view, sides are parallel and inflated; LV overlapping right at the anterodorsal angle. Surface covered with weak reticulation, the ventral ridge rising at the anterior ridge and runs almost parallel to the ventral

Explanation of Plate 3

Figs. 1-3, Pokornyella sp. Locality IGM-2, 515. All specimens are approximately X 70: fig. 1, Hypotype IGM-353-Mi, C, external view of the RV; fig. 2, Hypotype IGM-354-Mi, C, external view of the LV; fig. 3, Hypotype IGM-355-Mi, C, dorsal view.

Figs. 4-6, Buntonia sp. Locality IGM-2,515, All specimens approximately X 100: fig. 4, Hypotype IGM-356-Mi, C, dorsal view; fig. 5, Hypotype IGM-357-Mi, C, external view of LV; fig. 6, Hypotype IGM-358-Mi, C, external view of RV.

Fig. 7-8, "Triginglymus" sp. Locality IGM-2, 515. All specimens approximately X 60: fig. 7, Hypotype IGM-359-Mi, male C, external view of $L V$; fig. 8, Hypotype IGM-360-Mi, female LV, external view.

Figs. 9-11, Loxoconcha sp. Locality USGS-84-TC-51. All specimens are approximately X 135; fig. 9, Hypotype IGM-361-Mi, C, dorsal view; fig. 10, Hypotype IGM-362-Mi, LV, external view; fig. 11, Hypotype IGM-363-Mi, RV, external view.

Fig. 12, Paracytheridea sp. Locality IGM-2, 515. Hypotype IGM-364-Mi, LV, external view, X 80. 

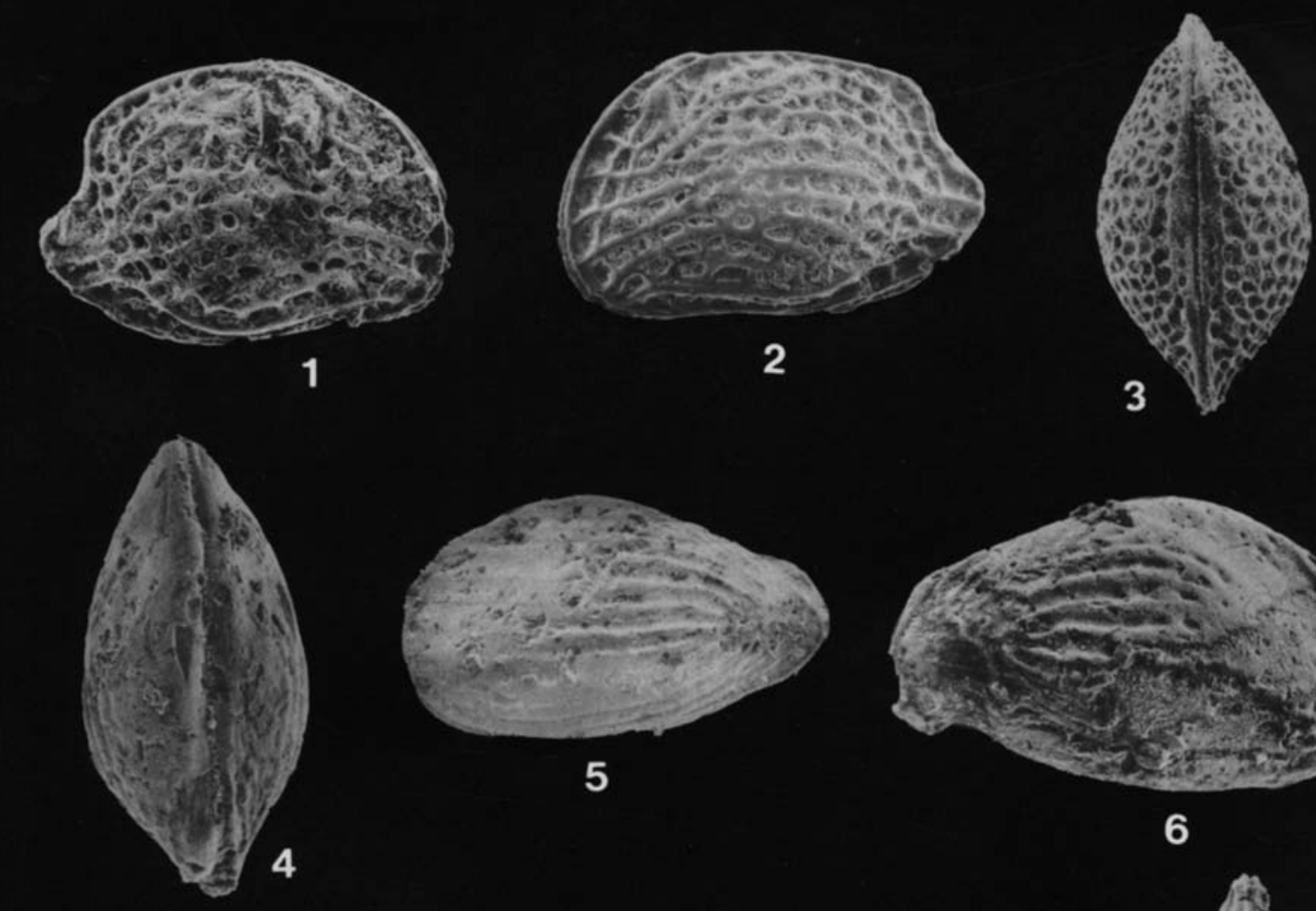

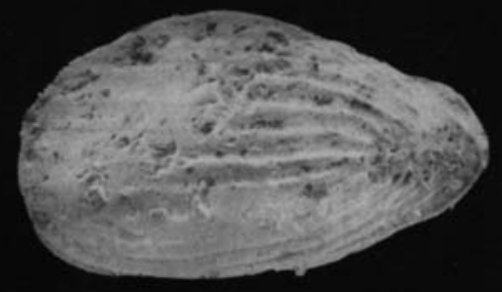

5

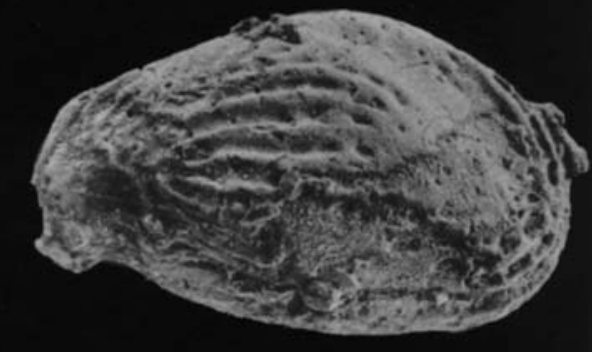

6

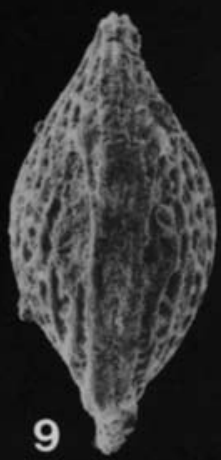

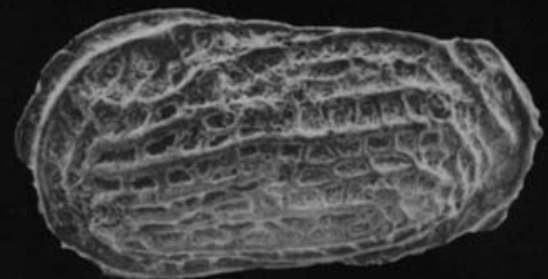

7

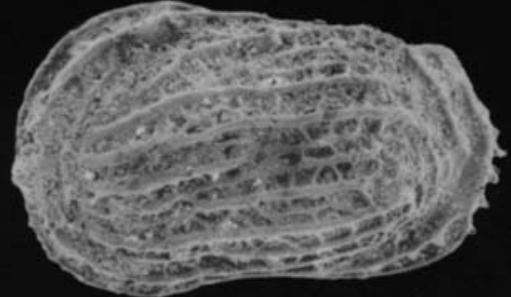

8

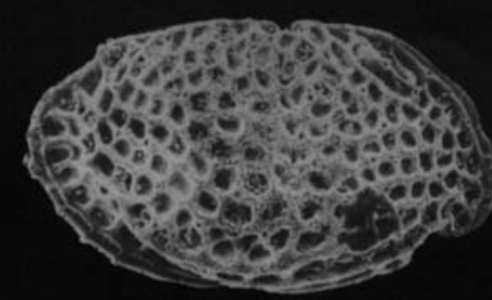

11

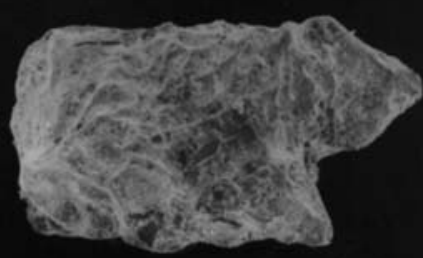

12 
margin ending at $1 / 5$ of the length from the posterior end; dorsal ridge oblique, extending from just below the eye tubercle and obscuring the posterior part of the dorsal margin, to a strong lateral wing-like projection in front of the posterior cardinal angle, where it turns downward and runs parallel to the posterodorsal margin.

Two subparallel longitudinal median ridges run $1 / 5$ from the anterior margin, where they are high, to $1 / 5$ before the posterior end. At the central point of the swelling, both ridges are interrupted and continue back as low ridges.

In internal view, valves are deep, hinge consists of a large rounded socket with a postjacent small subconical tooth, the median element is a smooth straight bar that ends in a very deep, large rounded socket. The adductor muscle scars consist of a vertical row of four scars and two frontal scars obscured by a shallow depression at the muscle platform. Sexual dimorphism, females higher than males.

$\begin{array}{llcc}\text { Dimensions (mm) } & & \mathrm{L} & \mathrm{H} \\ \text { Holotype LV } & \text { IGM-344-Mi } & 0.844 & 0.533 \\ \text { Paratype RV } & \text { IGM-345-Mi } & 0.800 & 0.450 \\ \text { Paratype C } & \text { IGM-346-Mi } & 0.780 & 0.430 \\ \text { Paratype LV } & \text { IGM-347-Mi } & 0.730 & 0.440\end{array}$

Remarks. The general outline of this species resembles the female carapace of Keij's (1957) Bradleya kaasschieteri from the upper Eocene of Belgium. It differs from the latter in the presence of two submedian ridges and in the pattern of the smaller ones.

Distribution. Locality USGS-84TC51.

\section{Jugosocythereis monrealensis Carreño \& Cronin, sp. nov.} (Pl 2 figs 9-12)

Derivation of name. After Rancho Batequi del Monreal.

Diagnosis. Carapace inflated, covered with numerous, large and irregular reticulated pattern; the median ridges characteristic of the genus very weakly developed.

Holotype. LV female IGM-348-Mi

Material. 27 specimens.

Locality and horizon. Locality IGM-2,515, $32 \mathrm{~km}$ southwest of San Ignacio, Baja California Sur, Mexico, northern side of Arroyo San Ramón, near Rancho Batequi del Monreal. Approximately $2.5 \mathrm{~km}$ northeast of the intersection of $27^{\circ} 00^{\prime}$ latitude $\mathrm{N}-113^{\circ} 00^{\prime}$ longitude $\mathrm{W}$. Mid Eocene age. Medium to very fine-grained, micaceous sandstone.

Description. The carapace is heavily calcified, subrectangular in lateral view; dorsal view irregularly sagittated with the anterior and posterior ends depressed. Laterally, dorsal margin nearly straight; ventral margin slightly convex; greatest convexity just anterior to the middle; greatest height at the anterior cardinal angle; greatest width at the mid-center because of the projection of the subcentral swelling. Anterior margin flattened and somewhat obliquely rounded, bearing a large rim likefringe projection, more evident from the mid-anterior to the cardinal angle, with approximately 23 small denticles, more conspicuous at the anteroventral margin. Posterior dorsal margin truncated and slightly concave, resulting in a blunt angle with the posteroventral margin, which has four blunt, large spines. The entire valve surface is covered by numerous, large and irregular fossae formed by thin murae, forming a reticulated pattern. Six large fossae occupy the anterior margin. Below the eye tubercle and behind the most anterodorsal fossae, there is a sulcus which is bordered by the emerging oblique dorsal ridge. This ridge extends back, obscuring the posterior part of the dorsal margin and ending in a strong lateral projection in front of the posterior cardinal angle. At this point, it turns downward running parallel to the posterodorsal margin almost to join the terminus of the ventral ridge. The ventral ridge is subparallel to the ventral margin. The characteristic median ridge of the genus is weakly developed in some specimens (females?), where it forms a short reticulated row of tubercles in RV. In other specimens (males?), one upper submedian ridge, emerging from the flattened anterior margin, runs slightly upward and disappears in front of the posterior cardinal angle. A second low submedian ridge, more evident in the RV and in juveniles, runs subparallel to the upper one, disappearing at about $1 / 6$ of the length from the posterior end. In the LV, this ridge is weaker and ends near the muscle platform, where a concentric reticulated pattern occurs.

Internally, the valve is deep. In the RV, the hinge has a strong conical anterior tooth and a small subovate postjacent socket with a medial smooth groove ending in a large ovate posterior socket. Adductor muscle scars pattern partially obscured, consists of an oblique row of four scars; there are numerous straight radial pore canals.

$\begin{array}{lllll}\text { Dimensions (mm) } & & \text { L } & \text { H } \\ \text { Holotype LV } & \text { female } & \text { IGM-348-Mi } & 0.760 & 0.470 \\ \text { Paratype RV } & \text { female } & \text { IGM-349-Mi } & 1.000 & 0.522 \\ \text { Allotype RV } & \text { male } & \text { IGM-350-Mi } & 0.922 & 0.544 \\ \text { Paratype C } & \text { female } & \text { IGM-351-Mi } & 1.000 & 0.522 \\ \text { Paratype C } & \text { female } & \text { IGM-352-Mi } & 0.900 & 0.520\end{array}$

Remarks. This species is similar to several other species described from the Gulf Coastal Plain and Florida. In dorsal view, it is similar to Jugosocythereis vicksburgensis (Howe \& Law, 1936) from the mid Oligocene, Vicksburg Group. Byram, Hinds County, Mississippi and J. bialata (Howe, 1951) from the mid Eocene, Avon Park limestone at Levy County, Florida. Nevertheless, this species is distinguishable by its conspicuous, flattened anterior margin and somewhat obliquely rounded margin, which bears a large rim like-fringe projection, carrying six large fossae. In addition, the characteristic median ridges of the genus are weakly developed in the species from the Bateque Formation.

Distribution. Locality IGM 2,251

\section{Tribe Pokornyellini Puri, 1974 \\ Genus Pokornyella Oertli, 1956 Pokornyella sp.}

(Pl 3 figs 1-3)

Diagnosis. Carapace medium size, heavy, thickest along median portion and near middle, subrectangular in lateral view, lenticular in dorsal view. Dorsal margin straight in LV, slightly curved in RV, ventral margin slightly sinuous, anterior margin broadly and obliquely rounded, posterior 
end blunt bearing two small ribs above where the posterodorsal slope is concave. A lower small rib extends from the posterior end, nearly parallel to ventral margin; near the anterior end, it forms a distinct ventral ridge. Surface ornamented with deep oval to quadrate coarse reticulation. Eye tubercle small. Internal characters were not observed because of the absence of isolated valves.

Hypotypes. C IGM-353-Mi; C IGM-354-Mi; C IGM-355-Mi. Material. 47 specimens.

Remarks. Disarticulated valves were not found and detailed observation of the internal characters was not possible. The abundance of well preserved carapaces permits comparison with other mid Eocene Pokornyella, particularly with similar species described from the Avon Park limestone, Levy County, Florida as P. cribaria (Howe, 1951) and P. bellula (Howe, 1951). The Bateque Formation species is bigger, more strongly ornamented, much slender in dorsal view and less quadrate in lateral view than the other species. In our opinion, this species represent a new taxa, but we prefer to leave it in open nomenclature because at the moment we can not fully describe it.

Distribution. Locality IGM 2, 515

\section{Subfamily Buntoniinae Apostelescu, 1961 \\ Genus Buntonia Howe, 1935 \\ Buntonia sp. \\ (Pl 3 fig 4-6)}

Remarks. Due to the scarce material and its poor preservation, it was impossible to identify this form to a specific level. Nevertheless, this species appears to be related to Buntonia shubutaensis Howe in Howe \& Chambers (1935), except for the fact that Buntonia shubutaensis is larger. Hypotypes. C IGM-356-Mi; C IGM-357-Mi; C IGM-358-Mi.

Material. 19 specimens.

Distribution. Locality IGM 2, 515

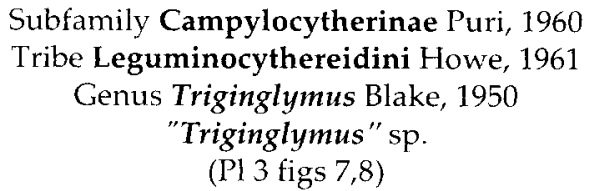

Diagnosis. Carapace elongated in lateral view, lanceolated in dorsal view with compressed posterior end; dorsal and ventral margins almost straight. Anterior end broadly and evenly rounded carrying several denticles in the midventral portion; posterior margin subangular with the dorsal portion slightly concave, ventral portion with six small rounded spines. Valves covered anteriorly with two low parallel rims, which continue along ventral and dorsal margins; surface coarsely reticulated with several prominent sinuate longitudinal ridges. Eye tubercle well developed. Inner characters were not observed because material consists of carapaces; nevertheless, it was possible to observe the LV hinge in a broken specimen, which consists of a large, rounded anterior socket and a postjacent blunt tooth followed by a triangular anti-slip tooth projection connected to an ovate socket by a median smooth bar. Males are more elongated than females.
Remarks. The hinge structure observed in this species suggests inclusion in the genus Triginglymus. Ornamentation is similar to that exhibited in T. longicostata (Blake, 1950) described from the mid Eocene of the Gosport sand from Clarke County, Alabama; nevertheless, the species from the Bateque Formation is bigger, more coarsely reticulated and with a denticulated anterior mid-ventral margin. We left this species in open nomenclature due to the lack of valves.

Hypotypes. C IGM-359-Mi; LV IGM-360-Mi.

Material. 7 specimens.

Distribution. Locality IGM 2, 251.

\section{Family Loxoconchidae Sars, 1861 \\ Genus Loxoconcha Sars, 1866 \\ Loxoconcha sp. \\ (Pl 3 figs 9-11)}

Diagnosis. Carapace small, inflated and ovate in dorsal view, dorsal margin straight, ventral margin concave. Anterior margin obliquely rounded, posterior margin in RV truncated dorsally, broadly rounded from mid-dorsally to ventrally; $L V$ is dorsally concave and slightly acute; ventrally $L V$ is obliquely rounded. Surface entirely covered with a quadrate to rectangular reticulated pattern.

Hypotypes. C IGM-361-Mi; LV IGM-362-Mi; RV IGM-363Mi.

Material. 9 specimens.

Remarks. This species is very close to Loxoconcha marionensis Puri, 1957 from the upper Eocene of the Crystal River Formation of Florida in its general outline, except for the presence in the Bateque material of a low dorsal keel. $L$. cocoaensis Krutak, 1961 is also similar but, in that species, the dorsal ridge is blade-like, instead of rounded as in Loxoconcha sp. from Baja California.

Distribution. Locality USGS-84TC51.

\section{Family Paracytherideidae Puri, 1957 \\ Genus Paracytheridea Müller, 1894 Paracytheridea sp.}

(Pl 3 fig 12)

Diagnosis. Carapace subrectangular in lateral view, strongly alated. Dorsal and ventral margins straight, anterior margin broadly rounded, posterior end draw out into a distinct caudal process. Each valve bears a strong ala which projects from the midventral zone, terminating at about $1 / 3$ the shell length from the posterior. Surface ornamented with a pattern of low, anastomosing ridges; anteriorly a group of four ridges radiates out from a point near the antero-ventral zone. Internal features typical for the genus.

Hypotypes. LV IGM-364-Mi; RV IGM-365-Mi.

Material. 4 specimens.

Remarks. Compared to other Eocene Paracytheridea species, the material from the Bateque Formation is similar to $P$. bastropensis Stephenson, 1947, but the former has a more elevated ventral alar projection, and a subacute posterior end. It is very closely related to $P$. belhavenensis Howe \& Chambers, 1935, but detailed comparison to the type 
specimen of this species shows that the distribution of the valves surface ridges is different and the subcircular depression located in the anteriomedian zone is not evident in the Bateque Formation species.

Distribution. Locality IGM 2, 251.

\section{Family Paracyprididae Sars, 1923 Genus Paracypris Sars, 1866 Paracypris sp.}

Diagnosis. Medium-sized carapace, smooth, elongated, subpyriform in lateral view, dorsal margin arched forming an angular peak at mid-portion, more conspicuous in LV, ventral margin straight to slightly concave particularly at the center, posterior end is narrow, subacute. LV overlaps RV throughouit, more strongly dorsally and ventrally.

Hypotypes. C IGM-366-Mi; C IGM-367-Mi.

Material. 21 specimens.

Remarks. The material consisted only of carapaces. This species resembles Paracypris licina (Huff, 1970), but differs in that it is smaller, and the dorsal margin has a small concavity at the anterior cardinal angle. P. franquesi Howe \& Chambers (1935) is much larger, and the dorsal margin has an angular peak at the anterior cardinal angle instead of at the mid-portion.

Distribution. Locality IGM 2, 251.

\section{Family Pontocyprididae Müller, 1894 Genus Argilloecia Sars, 1866 Argilloecia sp.}

Diagnosis. Carapace elongated, highest just anterior to the middle. Anterior margin irregularly rounded, almost angulated just above the middle. Dorsal margin straight or very gently convex in the middle, curving gently downward at each extremity. Ventral margin very slightly convex along its whole length. Posterior margin obliquely rounded, blunt. Muscle scars typical of the genus.

Hypotypes. C IGM-368-Mi; C IGM-369-Mi; C IGM-370-Mi.

Material. 12 specimens.

Remarks. This species resembles Argilloecia in all respects except that it has reversed hinge overlap. The material of the Bateque Formation only consists of carapaces so the muscle scars could only be observed through the semitransparent carapace. The marginal area was not observed in detail.

Distribution. Locality USGS-84TC51

\section{DISCUSSION}

The foraminifers associated with the ostracod fauna of the Bateque Formation are characteristic of the Hantkenina nuttalli Interval Zone and Globigerinatheka subconglobata subconglobata Concurrent Range Zone, suggesting a mid Eocene age of 50.3 - 54.1 Ma (Toumarkine \& Luterbacher, 1985).

Sorensen (1982) and McLean and coworkers (1987) reported Bateque sandstones, yielding abundant fragmented shallow-water fossils, in a predominantly deepwater assemblage interpreted as significant downslope transport. The diatomaceous deposits suggest outer-shelf to upper-slope paleodepths affected by strong upwelling (McLean \& Barron, 1988).

At locality IGM 2,215, the presence of Pseudophragmina (Proporocyclina) flintensis and Amphistegina lopeztrigoi indicates a shallow, warm-water environment, deposited at a depth of no more than $100 \mathrm{~m}$ (Vaughan, 1945); whereas Thaerocytherinii, that constitutes more than $90 \%$, reinforces the interpretation that deposition occured in an outer-neritic environment. Dominance of carapaces vs. valves could indicate rapid burial in a deeper part of the basin.

At USGS 84TC51 locality, the exposed lithology consists mostly of very fine sandstone with interbedding fossiliferous lenses, locally rich in well preserved stromatolites, coralline algae, foraminifers, calcareous sponges, gastropods, and bivalves (Squires \& Demetrion, $1989,1990 \mathrm{a}, \mathrm{b})$. No deep-water ostracods were found and the assemblage is dominated by thick-shelled Trachyleberdidae (Bajacythere, Occultocythereis, Jugosocythereis), suggesting an outer-neritic environment. The associated benthic foraminifers are characteristically outer-neritic morphotypes.

The ostracod assemblage is a mixture of faunas from different paleobiogeographic provinces. In general, the whole ostracod assemblage has strong taxonomic affinities with the Eocene of the Gulf Coast and the Mediterranean. This suggests a marked influence of the Tethyan corridor as a means for tropical species latitudinal dispersal during the Eocene.

The species Paijenborchella trigona has previously been reported from the Californian Province and, together with the six new species (including Paijenborchella mezquitalensis) and the new genus Bajacythere, constitutes an isolated record of the Eocene ostracod fauna in the area. Paijenborchella is a typical Mesozoic and Paleogene genus from Europe and its presence in America's Eocene sediments strongly reinforces its Tethyan origin. Paijenborchella is also present in California during the Late Cretaceous (Holden, 1964).

The new genus Bajacythere raises an interesting paleogeographic problem. This species is similar to species found in the Equatorial Pacific Ocean at Enewetak Atoll in upper Miocene to Holocene sediments (Cronin, unpublished data) and also seems to be closely related to Maastrichtian species reported from Europe (i. e. Cythereis anorchidea Veen, 1935). The Tethyan influence on the paleogeographic distribution of this genus is presently not certain.

In summary, the Eocene Baja ostracod assemblage provides important new data to our understanding of circum tropical Tethyan ostracod paleobiogeography.

\section{ACKNOWLEDGMENTS}

A. L. Carreño gratefully acknowledges Dr. J. Pojeta, for the provided facilities during my stay at the United States Geological Survey, Reston, Virginia, supported by Consejo Nacional de Ciencia y Tecnología. Dirección General de Asuntos del Personal Académico, UNAM and Universidad Autónoma de Baja California Sur, gave logistic support. 
Technical assistance of M. Alcayde-Orraca, from the staff of the Instituto de Geologia, was also very valuable. I am indebted to Margarita Cronin for all her kindnesses. We thank Dr. J. E. Hazel (Louisiana State University), Dr. K. L. Finger (Chevron Oil Field Research Company) and R. Blodgett (United State Geological Survey) for their patience in improving early drafts. Thanks also to Alvin M. Phillips, Curator of the Henry V. Howe Collection (Museum of Geosciences Louisiana State University) for his help. The authors are also indebted with two anonymous reviewers.

\section{Manuscript received April 1992}

Manuscript accepted August 1993

\section{REFERENCES}

Blake, D.B. 1950. Gosport Eocene Ostracoda from Little Stave Creek, Alabama. Journal of Paleontology, Menasha, Wis., 24(2):172-284.

Brady, G.S. 1866. On new or imperfectly known species of Ostracoda. Transactions of the Zoological Society of London, London, 5:359-398.

Brady, G.S. 1880. Report on the Ostracoda dredged by H.M.S. Challenger during the years 1873-1876. Reports of the Voyage of H. M. S. Challenger, Zoology, London, 1(pt. 3):1-184.

Butterlin, J. 1981. Claves para la determinación de macroforaminiferos de México y del Caribe, del Cretácico Superior al Mioceno medio. Instituto Mexicano del Petróleo, Subdirección de Tecnología y Exploración, Mexico, D.F.:1-219.

Carrillo de Isolbi, G. 1976. Geología regional semidetallada del prospecto San Ignacio-Cadejé, Baja California Sur. Unpub. B. Sc. thesis, Universidad Nacional Autónoma de Mexico, Facultad de Ingenieria:1-210.

Gooch, D.D. 1938. Some Ostracoda of the genus Cythereis from the Cook Mountain Eocene of Louisiana. Journal of Paleontology, Menasha, Wis., 13(6):580-588.

CGSNEGI, 1983. San José de Gracia, Baja California Sur. Mexico, D.F., Secretaria de Programación y Presupuesto, Coordinación General de los Servicios Nacionales de Estadistica, Geografia e Informática, Dirección General de Geografía, topographic chart number G12A64, scale 1:50,000.

Heim, A. 1922. Notes on the Tertiary of southern lower California. Geological Magazine, London, 59(702):529-547.

Holden, J.C. 1964. Upper Cretaceous ostracods from California. Palaeontology, London, 7(3):393-429.

Howe, H.V. 1951. New Tertiary ostracode fauna from Levy County, Florida. Florida Geological Survey, Bulletin, Florida, Fla., (34):1-32.

Howe, H.V. \& Chambers, J. 1935. Louisiana Jackson Eocene Ostracoda. Department of Conservation Louisiana Geological Survey, Bulletin, New Orleans, La., (5):1-65.

Howe, H.V. \& Law, J. 1936. Louisiana Vicksburg Oligocene Ostracoda. Department of Conservation Louisiana Geological Survey, Bulletin, New Orleans, La. (7):1-96.

INEGI, 1982. San Isidro, Baja California Sur. Mexico, D.F., Secretaria de Programación y Presupuesto, Instituto Nacional de Estadistica, Geografía e Informática, topographic chart number NG12-4, scale 1:50,000.

Huff, W.J. 1970. The Jackson Eocene Ostracoda of Mississippi. Mississippi Geological, Economic and Topographical Survey, Bulletin, Jackson, Miss.:1-289.

Keij, A.J. 1957. Eocene and Oligocene Ostracoda from Belgium. Institut Royal des Sciences Naturelles de Belgique, Mémoires,
Brussels, (136): 1-210.

Krutak, P.R. 1961. Jackson Eocene Ostracoda from the Cocoa Sand of Alabama. Journal of Paleontology, Tulsa, Okla., 35(4):769-788.

Marianos, A.W. \& Valentine, J.W. 1958. Eocene ostracode fauna from Marysville Buttes, California. Micropaleontology, New York, N.Y., 4(4): 363-372.

McLean, H. \& Barron, J.A. 1988. A late middle Eocene diatomite in northwestern Baja California Sur, Mexico: implications for tectonic translation. In Filewicz, M.V., \& Squires, R.L., (Eds.), Paleogene Stratigraphy, west coast of North America. Pacific Section, Society of Economic Paleontologist and Mineralogists, West Coast Paleogene Symposium, Santa Barbara, Calif., 58:1-8.

McLean, H., Hausback, B.P. \& Knapp, J.H. 1985. Reconnaissance geological map of part of the San Isidro quadrangle, Baja California Sur, Mexico. U.S. Geological Survey, Miscellaneous Field Studies Map, MF-1779, scale 1:250,000, Reston, Va., one sheet.

McLean, H., Hausback, B.P. \& Knapp, J.H. 1987. The geology of west-central Baja California Sur, Mexico. U.S. Geological Survey Bulletin, Reston, Va., 1579:1-19

Mina-Uhink, F. 1957. Bosquejo geológico del territorio de la Baja California. Boletín de la Asociación Mexicana de Geólogos Petroleros, Mexico, D.F., 9(3-4):139-269.

Okada, H. \& Bukry, D. 1980. Supplementary modification and introduction of code numbers to the low-latitude coccolith biostratigraphic zonation (Bukry, 1973; 1975). Marine Micropaleontology, Amsterdam, 5(3):321-325.

Puri, H.S. 1957. Stratigraphy and zonation of the Ocala Group, Part 3. Ostracoda. Florida Geological Survey, Bulletin, Tallahassee, Fla., (38):1-248.

Sorensen, P.A. 1982. Sedimentology and sedimentary petrology of a Paleocene basin near Laguna San Ignacio, Estado de Baja California Sur Mexico. Unpub. M. Sc. thesis, University of California Santa Barbara, $114 \mathrm{p}$.

Squires, R.L. \& Demetrion, R. 1989. An early Eocene pharetronid sponge from the Bateque Formation, Baja California Sur, Mexico. Journal of Paleontology, Lawrence, Ka., 63(4):440-442.

Squires, R.L. \& Demetrion, R. 1990. New early Eocene marine gastropods from Baja California Sur, Mexico. Journal of Paleontology, Lawrence, Ka., 64 (1):99-103.

Squires, R.L. \& Demetrion, R. 1990. New Eocene marine bivalves from Baja California Sur, Mexico. Journal of Paleontology, Lawrence, Ka., 64(3):382-391.

Stephenson, M.B. 1944. Ostracoda from the Reklaw Eocene of Bastrop County, Texas. Journal of Paleontology, Tulsa, Okla. 18(5):448-454.

Stephenson, M.B. 1947. Weches Eocene Ostracoda: corrections. Journal of Paleontology, Menasha, Wiss., 21 (6):579.

Toumarkine, M. \& Luterbacher, H. 1985. Paleocene and Eocene planktic foraminifera. In Bolli, H.M., Saunders, J.B., \& PerchNielsen, K., (Eds.), Plankton Stratigraphy, 87-154, Cambridge University Press.

Vaughan, T.W. 1945. American Paleocene and Eocene larger Foraminifera. Geological Society of America Memoir, Baltimore, Md, 9(1):1-175.

Veen, J.E. 1936. Die Cytheridae der Maastrichter Tuffkreide und des Kunrader Korallenkalkes von süd-Limburg. IV Die Gattungen Cythereis, Archicythereis und Cytherideis. Natuurhistorisch Maandbl. Maastricht, 25(11-12):131-168. 